\title{
Tangence
}

\section{Vancouver - Rim of the Park}

\section{Laurie Ricou}

Numéro 48, octobre 1995

Montréal et Vancouver : parcours urbains dans la littérature et le cinéma

URI : https://id.erudit.org/iderudit/025859ar

DOI : https://doi.org/10.7202/025859ar

Aller au sommaire du numéro

Éditeur(s)

Tangence

ISSN

0226-9554 (imprimé)

1710-0305 (numérique)

Découvrir la revue

Citer cet article

Ricou, L. (1995). Vancouver - Rim of the Park. Tangence, (48), 24-30.

https://doi.org/10.7202/025859ar d'utilisation que vous pouvez consulter en ligne.

https://apropos.erudit.org/fr/usagers/politique-dutilisation/ 


\title{
Vancouver-Rim of the Park
}

\section{Laurie Ricou}

\begin{abstract}
There are two certainties that the schools neglect to teach us. One is a law of relative compensation for example 'I am a plain woman but I live near Stanley Park \& the Ocean...'

Ethel Wilson, in a manuscript draft of the story "Fog." 1
\end{abstract}

Perhaps less certain, but equally whimsical, is my law for writing Vancouver. Call it the law of relative designations: It is a plain city but it lies near Stanley Park \& the Ocean. In Keith Maillard's Two Strand River (1978) the city has no personality but 'a hell of a view': "Vancouver . . . seemed from this height and distance as remotely attractive as a picture portrait : the buildings of the West End, English Bay, the mountains." 2 A city more to be looked at than lived in. Or looked away from. And just at its northern and western edge, rain forest and ocean, trails and totems. There Leslie, the novel's central character, hears the story-of spirit quest and shaman-which Vancouver would not tell.

Florence McNeil finds the title for her second book in the love(?) poem "Rim of the Park." 3 Thus, she focusses her poems of apprenticeship to beach trails and family records in a compact dramatic monologue staged near Stanley Park and the ocean. One rim of the park is a sea wall, 59 years in the building, five and a half miles in length. ${ }^{4}$ In the poem, the "wall" is not a barrier to keep something in or out, but animate, equine: "On this

1 The epigraph is a passage cleleted from the published version of "Fog" ( $M \mathrm{~s}$. Golightly and Other Stories 1961, NCL Edition, Toronto, McClelland and Stewart, 1990). See Ethel Wilson Papers, Special Collections, University of British Columbia Library Box 6 Folder 13 [p. 4].

2 Keith Maillard, Two Strand River, Toronto, General Publishing, 1982, p. 213.

3 Florence MoNeil, 7he Rim of the Park, Port Clements, 13.C., Sono Nis Press, 1972, p. 31.

4 Chuck Davis, gen. ed., The Vanconter Book, North Vancouver, J.J. Douglas, 1976. 
wall we're riding / the spun water with real fish / gouging seaweed." 5 The shadowed horse implied by the verb "riding" changes quickly into liquid ("water") and fabric ("spun"), the rim's stability further undermined by fish digging into the layers and faults of the wall. The apartment buildings claim the place in the name of "geraniums." The city is "windows" and flowers. The boundary of the park is a transition zone, where the solidly geological metamorphoses swiftly, imperceptibly into water and animal.

The root meaning of park is an 'enclosure for beasts.' At one time or another, Stanley Park has incorporated "a buffalo paddock, an elk grounds, a deer run," ${ }^{6}$ and an aquarium, said to have been Timothy Findley's inspiration for Not wanted on the voyage. At first, the "dark zoo / in the center of / the park" seems to threaten the lovers as the speaker impatiently hurries them away from seaweed and snapshots, perhaps to a tryst in one of the nearby apartments. But the syntax is deliberately ambivalent: the zoo may be a centre of "quiet, "-and the city a site for contemplating and absorbing the power of the beasts.

"It is common knowledge" intones the narrator of Michael Slade's clinically bloody thriller Headbunter (1984), "that for physical setting there are only six great cities in the world. Rio de Janeiro, Sydney, Cape Town, Hong Kong and San Francisco: these are five of them. Vancouver is the sixth one. "7 In this formulation, Vancouver is the afterthought. Vancouver is the city that does not immediately come to mind. Unlike the other five it has no identifiable personality as city. Transplanted and set at the junction of the Red and the Assiniboine, Rio and Hong Kong would still be great cities; Vancouver without sea and mountains would disappear.

Vancouver is incidental to its setting. It may be bland, or have the highest rate of violent crime in the country, or have a bankrupt symphony orchestra, but it is near Stanley Park. Formulating, or reiterating, this law of relative location, I am choosing a

5 Florence McNeil, The Rim of the Park, p. 31.

6 Robert A.J. McDonald, "'Holy retreat' or 'practical breathing spot'? class perceptions of Vancouver's Stanley Park; 1910-1913," Canadian Historical Review, 65, no. 2, 1984, p. 127-153.

7 Michael slade pseud., Headhunter, New York, William Morrow, 1984, p. 25. 
26

way of understanding the city that answers my own need for escape. It embraces the clichés of Lotusland and outdoor tennis in January, but it also recognizes the complexity of the park as local history and trope, and the instability of the rim.

Headbunter points the cliché by incorporating the phrasing of the tourist and convention bureau:

Every great city, no matter what size, has by definition at least one major park. For there must be some place where its citizens can escape from the hustle. London has Hyde Park. New York has Central Park. Paris has the Bois de Boulogne. Vancouver has Stanley Park. ${ }^{8}$

But in London, New York, and Paris the hustle is the city. Mount Royal is also central, and city and park share a (double) name. But Vancouver is constructed as the border or edge of the park. It is a frame and thus definition to the park and shows the viewer how to look at the park, not the city.

Vancouver is rim, an edge for the vessel, or strip of metal held in place by the hub and spokes of the park. Being on the rim, the city can at any moment slip into park-ness. I would propose Malcolm Lowry's "Ghostkeeper" as the definitive rim of the park story. Lowry focuses the story, insofar as it can be said to be focused at all, on an elusively multiple writer-adventurer, one of whose personalities is named Tom Goodheart. Goodheart is apparently one of the city's leading local newspaper columnists, whose popularity is based on writing Vancouver by " walk[ing] in the park' to get most of his stories." The verbal form for Vancouver in Lowry's configuration is a journalist's notebook-scribbles for a 500 word newspaper column that really wants to be a much longer story titled "I Walk in the Park" (or any other of the six titles included in the notebook). In this story on the absurdity of plotting, essentially the only narrative line is the quite identifiable circuit of the rim of the park, from the tennis courts out to Prospect Point, then back past the zoo to Lost Lagoon (supposedly named by Pauline Johnson), and hence toward Lowry's focus on the supernatural (long before Tourism BC sloganized the word). The Goodhearts' apartment, where a city story might be set, is a vague pres-

8 Michael Slade, Headbunter, p. 221.

9 Malcolm Lowry, "Ghostkeeper," Wayne Grady, ed., The Penguin Book of Canadian Short Stories, Harmondsworth, Penguin Books, 1980, pp. 139-65. 
ence; the park, "dark pines and weeping willows, like fountains of gold thread, when the sun struck them, or bronze harp strings when it didn't," ${ }^{10}$ is a tour de force of metaphor. Vancouver's "human interest stories" 11 are found walking along "a path that followed the seashore almost on shorelevel", 12 on the one side the sea and a wrecked lifeboat, on the other "something unearthly ... like Paradise in a Flemish painting." 13

Configuring the city as the rim of the park has probably persisted because the park's symbolic value goes well beyond the connotations of the ornamental, aesthetic and idyllic. Lowry himself remembers the history of logging in the park, ${ }^{14}$ and like McNeil, knows the "dark zoo" is an important element in the park's repertoire of associations. What is now Stanley Park once contained five logging camps and a network of skid roads. ${ }^{15} \mathrm{Be}$ fore that it was an early summer home for the Squamish people. ${ }^{16}$ It is a shell midden and Indian burial ground. And 50 million years ago it was the site of "minor episodes of basaltic volcanism ... [that] helped to shape Siwash Rock and Prospect Point." 17 Stanley Park was preserved from complete urbanization because it was set aside in 1863 for a military reserve: when the Americans tried to invade, we would shut off the First Narrows. The first resolution of Vancouver's first city council was to petition the federal government to make the military reserve a park. (It was turned over in 1887.) Its quality as micro-climate is striking: the difference in surface air temperature between downtown Vancouver and the park is as high as $8^{\circ}$ Celsius. ${ }^{18}$

More resonant than any of these historical details, perhaps, is the ideal of the park as an expression of community, an opportunity for and a definition of social levelling. The grandest expression of the crowded paradise was the vision of Thomas Mawson, prominent British landscape architect, who presented to the

\footnotetext{
10 Malcolm Lowry, "Ghostkeeper," p. 139.

11 Malcolm Lowry, "Ghostkeeper," p. 142.

12 Makolm Lowry, "Ghostkeeper," p. 139.

13 Malcolm Lowry, "Ghostkeeper," p. 145.

14 Malcolm Lowry, "Ghostkeeper," p. 144-145.

15 Graeme Wynn \& Timothy Oke, eds., Vancouver and its Region, Vancouver, University of British Columbia Press, 1992, p. 65.

16 Graeme Wynn \& Timothy Oke, eds., Vancouver and its Region, p. 39-41.

17 Graeme Wynn \& Timothy Oke, eds., Vancouver and its Region, p. 18.

18 Graeme Wynn \& Timothy Oke, eds., Vancouver and its Region, p. 160.
} 
28

Canadian Club in 1912 his proposal that Georgia Street be widened and restricted to pedestrians so that it might become Vancouver's Champs Elysées:

in Coal Harbour I would have my Grande Rond . . . [with the pond at its centre as] the great social centre of Vancouver, where rich and poor, the rough man and the spring poet, would have to rub shoulders and pass along in comfort and ease. ${ }^{19}$

Hence, perhaps, the appeal of this setting to Lowry, who could wear the masks of both rough man and spring poet. Governor-General Lord Stanley dedicated the park "to the use and enjoyment of peoples of all colours, creeds and customs, for all times . . .". ${ }^{20}$ But, as R.A.J. McDonald points out, in an irony that did not escape Lowry, such rhetoric masks the likelihood that 960 acres of park can substitute for addressing poverty and class difference-that the park functions as a "mechanism for social control." 21

When Frankie, the awkwardly precocious narrator of Ethel Wilson's Hetty Dorval (1947), is sent from Lytton to the Coast for school, she has but one sense of the city-Vancouver is a boarding school at the edge of Stanley Park:

We were so near to Stanley Park that it was our playground and paradise. We liked our bedrooms on the top floor because we saw into the Park and across the lagoon. ${ }^{22}$

Like her creator, perhaps, who lived at Beach Avenue and Nicola, on the rim of the park, for over 40 years, Frankie's lifelong definition of the city consists in a view over the park to the mountains beyond. Perhaps she even learns to write, learns "the potent and insinuating quality of line" by contemplating the "soft clarity" of the Sleeping Beauty reflected in a round mirror. ${ }^{23}$

Hetty Dorval indicates how my argument about Stanley Park extends to a wider sense of the non-urban world as park. City is not buildings and shops but a view of and over park. The moun-

19 Graeme Wynn \& Timothy Oke, eds., Vancouver and its Region, p. 118-120.

20. Chuck Davis gen. ed., The Vancouver Book, p. 29.

21 Robert A.J. McDonald, "'Holy retreat' or 'practical breathing spot,' " Canadian Historical Review, 65, no 2, 1984, 128.

22 Ethel Wilson, Hetty Dorval, Toronto, McClelland and Stewart, 1990, p. 50-51.

23 Ethel Wilson, Hetty Dorval, p. 51. 
tains don't rise abruptly to drive you mad, but are integral to the idea of the park: in Vancouver, "the mountains are beautiful and moderate and are at a moderate distance." 24

Of course, these mountains are not quite as benign in that other crucial story of reflected mountains, Wilson's "The Window." But the mountain-in-the-park/park-as-wilderness fusion figures even in that story. Allan Fotheringham is very fond of describing the city as the edge of nowhere:

... drive up through the swimming pools on Martini Mountain where the expense accounts dwell-an explorer immediately hits dense forest and could walk, theoretically, straight to the North Pole without encountering a single human being. ${ }^{25}$

As I read this, particularly in context (the column I'm quoting from is titled 'Smelling flowers in the slow lane'), Fotheringham is exploring another version of the rim of the park figure. The unpeopled spaces - they are not uninhabited, of course, but that's another subject-are like Hetty's mountains, "beautiful and moderate." And, to come back across the Lion's Gate to the shellmidden-come-coal mine where the spirits of Pauline Johnson and Robbie Burns brood, Stanley Park, even bisected by a terrifying three-lane highway, can still claim to be primeval:

The circumstances of Stanley Park's formation in the 1880s had not required a full articulation of park principles. The forest already existed. ... The city's laissez-faire attitude . . . had not required that [idealists] publicly defend the park's wilderness features. ${ }^{26}$

Old growth forest is another form of park and it governs by the law of relative compensation.

My theme is the rim of park. A fault line. The rim is neither inside nor out. It's sloping, slipping. But I think it has merit as an explanatory tool. The ecologists' term "ecotone" seems to apply. Ecotone describes a junction zone between two diverse communities-forest and grassland, for example, where we can observe increased variety and density of organisms. "Usually an

24 Ethel Wilson, Hetty Dorval, p. 65-6.

25 Allan Fotheringham, "Smelling flowers in the slow lane," Maclean's, $24 \mathrm{Au}-$ gust 1992, p. 64 .

26 Robert A.J. McDonald, "Holy retreat' or 'practical breathing spot," Canadian Historical Review, 65, no 2, 1984, 128. 
30

ecotonal community contains many organisms from each of the overlapping communities, in addition to organisms characteristic of, and often restricted to, the ecotone." 27

Such "half thoughts / wheeling ... with persistence of hunger / or floating on scraps of flotsam" are the sort that might occur on a "November['s] walk near false creek mouth." That poem, which frequently apprehends several versions of holocaust, piles in repetitions and compounds the shared and unique species of the ecotone. Walking around the rim of the park, the narrator speaks the dynamic of animate/inanimate interchange. Earle Birney, whose poem this is, writes on the edge, "dreaming my own unraveled plots / between eating water and eaten shore." 28 His is perhaps the most important, evocative version of the rim of the park idea-that Vancouver imagines itself as on the edge of something else: a city which is not a city but could be (without freeways), a tremor between animal and human, a place to work and a place to play. As the News Herald imaged Stanley Park in 1889:

A city that has been carved out of the forest should maintain somewhere in its boundaries, evidence of what it once was, and so long as Stanley Park remains unspoiled that testimony to the giant trees which occupied the site of Vancouver in former days will remain. ${ }^{29}$

For Sharon Thesen, contrasting Vancouver to Montreal, the 'edge effect,' as on the rim of Ethel Wilson's park, creates "optical illusions." And maybe what I'm talking about here is all illusion, but that's the way my language sees it :

Stalked by mountains tracked by benign \& rusty freighters

bitten by blossoms extravagant

\& common, the walkers will find a place

by the water to sit for a minute

looking out. The world

turns to scenery again

and things hold still. ${ }^{30}$

27 Julie Thompson Klein, Interdisciplinarity, Detroit, Wayne State University Press, 1991, p. 91.

28 Earle Birney, Gbost in the Wheels: Selected Poems, Toronto, McClelland and Stewart, 1977 , p. 88.

29 Graeme Wynn \& Timothy Oke, eds., Vancouver and its Region, p. 166.

30 Sharon Thesen, Radio New France Radio, Vancouver, Slug Press, 1981. 